\title{
Knowledge, attitude, and practices of cattle farmers regarding zoonotic diseases in Erzurum, Turkey
}

\author{
Hayrunnisa Özlïa, Mustafa Atasever ${ }^{b}$, Meryem Aydemir Atasever ${ }^{b}$
}

\begin{abstract}
This study aimed to determine the knowledge, attitude, and practices of cattle farmers regarding zoonotic diseases in Erzurum, Turkey, where cattle-raising is the most common occupation. A cross-sectional study was conducted on 1,045 cattle farmers in Erzurum. In terms of the diseases that can be transmitted from animal to human, $69.6 \%$ of the cattle farmers had information on anthrax, $62.8 \%$ on brucellosis, $18.4 \%$ on tuberculosis, $44.9 \%$ on rabies, $32.5 \%$ on Crimean-Congo hemorrhagic fever, $8.9 \%$ on hydatid cyst, $8.0 \%$ on toxoplasmosis and $7.9 \%$ on giardiasis. The knowledge level of cattle farmers who were university graduates was $94.8 \%$. Cattle farmers having over 100 cattle had a knowledge level of $96.7 \%$ on zoonotic diseases and their positive attitudes and practices reached $95.1 \%$ and $91.8 \%$, respectively. The results showed that the increase in education status, size of the enterprise, and monthly income of cattle farmers was related to an increase in knowledge, attitude, and practices regarding zoonotic diseases. However, it was found that the positive knowledge and attitudes of the cattle farmers could not be transformed into positive practices evenly.

Key words: zoonotic disease, cattle farmer, public health, knowledge level.
\end{abstract}

\section{INTRODUCTION}

Zoonotic diseases (also known as zoonoses) are caused by pathogens that spread between animals and people ${ }^{1}$. On a global scale, an estimated $60 \%$ of known infectious diseases and up to $75 \%$ of new or reemerging infectious diseases are zoonoses (Salyer et al 2017). Zoonotic diseases are known to be the cause of nearly 2.5 billion people getting sick per year and lead to 2.7 million deaths among sick ones annually (Magwedere et al 2012).

Domestic and wild animal population movements have a role in the occurrence and spread of zoonoses (Shanko et al 2015). On the other hand, the trend in increasing urban green spaces and spatial expansion of urbanised areas into agricultural and natural habitats also increases the dispersal and abundance of vectors into urban areas and their contact with humans (Tomassone et al 2018). Moreover, unofficially traded animals are a much greater risk factor for disease spread because they are not necessarily subject to veterinary controls (Fèvre et al 2016). The animals with sub-clinic infections disease cannot be distinguished from healthy animals and, therefore, diseases can be carried into different regions by animal movements (Hardstaff et al 2015). Some occupations require contact with animals and one of these is livestock farming. Livestock farmers are particularly exposed to

Received: 01.04.2020.

Accepted: 14.08.2020.

aDepartment of Nutrition and Dietetics, Faculty of Health Sciences, Atatürk University, Erzurum, Turkey.

bDepartment of Food Hygiene and Technology, Faculty of Veterinary Medicine, Atatürk University, Erzurum, Turkey.

*Corresponding author: H Özlü; hayrunnisa@ atauni.edu.tr

1 CDC, Centers for Disease Control and Prevention. 2020. Zoonotic diseases. Available at: https://www.cdc.gov/onehealth/basics/zoonotic-diseases.html; last accessed 15.06.2020. zoonotic risks. Additionally, the lack of basic knowledge level, biosecurity precautions, and personal hygiene of livestock farmers can play a part in the infection and spread of zoonotic diseases (Weese et al 2002, Cediel et al 2012). Within the concept of activities occurring in the interface of human, animal, and environment, livestock farmers who have knowledge about zoonotic diseases can act more willingly in taking precautions and attending disease control programs.

Zoonotic diseases are important public health issues worldwide, including Turkey. Turkey, its geographical location and structure are exposed to many zoonotic diseases, including 107 different zoonotic infections such as Anthrax, brucellosis, rabies, Crimean-Congo hemorrhagic fever (CCHF) or tularemia (Inci et al 2018). Other zoonotic diseases investigated in this study, except for toxoplasmosis with a low incidence in cold areas, are seen much more frequently in intensive livestock farming regions in Turkey such as East Anatolia, Central Anatolia and Southeastern Anatolia (Ministry of Health 2011).

The East Anatolia Region, with $21 \%$ of the total area of Turkey, has crucial potential in terms of agriculture and livestock (Ateş and Terin 2008, TUIK 2018). Erzurum is the biggest province of the East Anatolia Region regarding surface area, and also has the highest amount of cattle. With 768,997 cattle, it is the second province of the country after Konya province in terms of the number of cattle (TUIK 2018). While some of the animals bred in the city are being used in animal production (Ünal 2011), about 20\% are sold alive out of the city ${ }^{2}$. In this city where livestock farming is performed heavily, cattle farmers play an integral role in implementing zoonotic diseases prevention and transmission. Their knowledge level on zoonotic diseases,

2 Anonymous. 2018. Republic of Turkey Ministry of Agriculture And Forestry Livestock Information System. Available at: https://hbs. tarbil.gov.tr 
attitude towards risks associated with livestock production and hygiene practices may affect disease risks to humans and animals. In this sense, very few studies have been conducted in the region with a local base (Çakmur et al 2015, Kuşaslan Avc1 et al 2017), and no studies had been carried out in Erzurum on this topic until now. This study aimed to determine the knowledge, attitude and practices of cattle farmers toward zoonotic diseases occurring in the city of Erzurum, Turkey, where animal breeding and livestock movement are performed intensely.

\section{MATERIAL AND METHODS}

This cross-sectional study was conducted between January 2016 and July 2017 on cattle enterprises located in 20 districts of Erzurum, Turkey. The province is the fourth largest city of Turkey and is located in the Eastern Anatolia region. Nearly $11 \%$ of Turkey's meadow and grasslands are in Erzurum.

The universe of the study consisted of 50,000 cattle enterprises located in 20 districts of the Erzurum province according to the 2016 Statistics of Animal Husbandry of Turkish Statistical Institute. Assuming that 50\% of the farmers would have knowledge about zoonotic diseases, the sample size was calculated as 1,045 with confidence $95 \%$ and sampling error $0.03 \%$. Questionnaires were handed out to enterprises selected using the random sample method and they were administered only to cattle farms, farmworkers and volunteers.

Data were collected using a questionnaire form that included 30 questions covering from demographic information to knowledge, attitudes and practices of cattle farmers regarding zoonotic diseases. The demographic information form included questions such as age, gender, number of children, educational status, monthly income and number of animals, and consisted of 10 questions. To evaluate the knowledge of the cattle farmers, certain questions were asked about important zoonotic diseases in Eastern Anatolia such as anthrax, brucellosis, tuberculosis, rabies, CCHF, toxoplasmosis, hydatid cyst, and giardiasis. Initially, the cattle farmers were asked if they had heard about the diseases transmitted from animals to humans and then they were told to identify which zoonotic diseases were transmitted to humans. The participants were informed of both the scientific and the local name of the diseases when doing the questionnaires. The questionnaire form containing the attitudes and practices related to zoonotic diseases included specific statements such as how do they dispose of animal waste, what protection equipment is being used when contacting animals, and what protective measures are being applied before consuming the obtained animal products.

Data were analysed using SPSS 20.0 software (SPSS Inc., Chicago, IL, USA). Percentage and frequency were examined as descriptive statistics. Pearson's chi-square was used to compare variables.

\section{RESULTS}

The study was conducted on 1,045 people aged between 18-79 years of which 1,015 (97.1\%) were male and 30 $(2.9 \%)$ were female. Out of the 1,045 cattle farmers who were the focus of the study, $134(12.8 \%)$ of them were university graduates while $14(1.34 \%)$ were illiterate. The number of married participants was 921 (88.1\%), amongst them, $520(56.5 \%)$ had less than five children and $13(1.4 \%)$ had more than 10 . The monthly income of the cattle farmers included in the questionnaire ranged between US\$ 350 and US\$ 8,500 (table 1).

It was established that $46.9 \%$ of cattle enterprises were dairy, $18.4 \%$ were fattening and $34.7 \%$ were mixed (dairy and fattening). The average cattle number was 39 and cattle farmers managed between three and 600 cattle. The number of enterprises with less than 10 cattle was 289 , 329 enterprises had 11-30 cattle, 200 enterprises had 31-50 cattle, 151 enterprises had 51-100 cattle and 76 of them had over 100 (figure 1). One hundred and fifty of these enterprises were dealing with sheep and goat breeding at the same time.

To measure the knowledge level of the participants about zoonotic diseases they were asked the following question: "Do you have any knowledge about the diseases transmitted from animals to humans?", and $80.2 \%$ of the participants responded positively (figure 2). These participants were then asked: "Which of these infect humans: anthrax,

Table 1. Socio-demographic characteristics of the cattle farmers.

\begin{tabular}{lrr}
\hline Characteristic & $\mathrm{n}$ & $\%$ \\
\hline Sex & 30 & 2.90 \\
Male & 1015 & 97.10 \\
Female & & \\
\hline Age & 47 & 4.50 \\
$<25$ & 276 & 26.41 \\
$25-40$ & 691 & 66.12 \\
$41-65$ & 31 & 2.97 \\
$65<$ & & \\
\hline Education level & 14 & 1.34 \\
Illiterate & 462 & 44.21 \\
Primary School & 199 & 19.10 \\
Secondary School & 236 & 22.60 \\
High School & 134 & 12.82 \\
University & & \\
\hline Monthly income (US\$) & 532 & 50.90 \\
$<850$ & 440 & 42.11 \\
$850-1700$ & 73 & 6.99 \\
$1700<$ & & \\
\hline
\end{tabular}

$\mathrm{n}$ : Number of cattle farmers. 


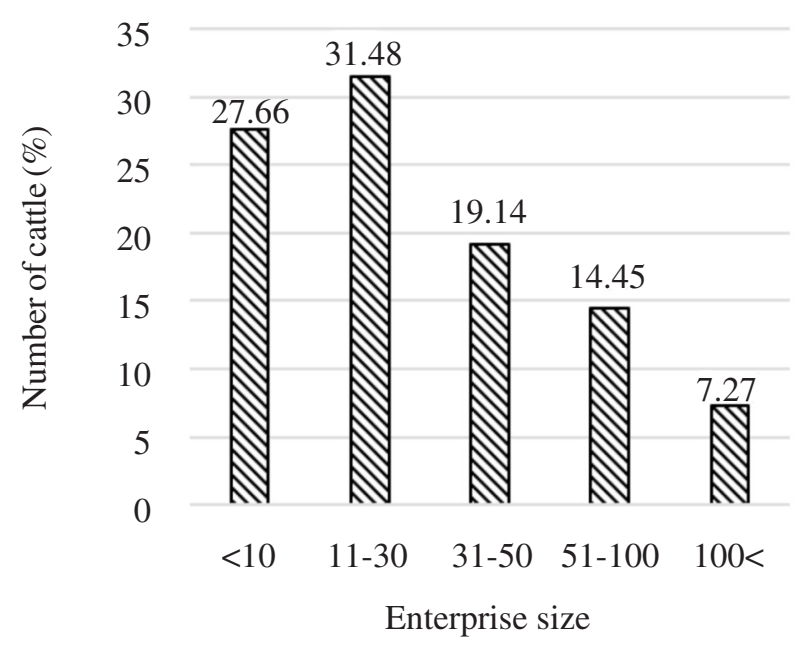

Figure 1. Enterprise size according to the number of cattle.

100

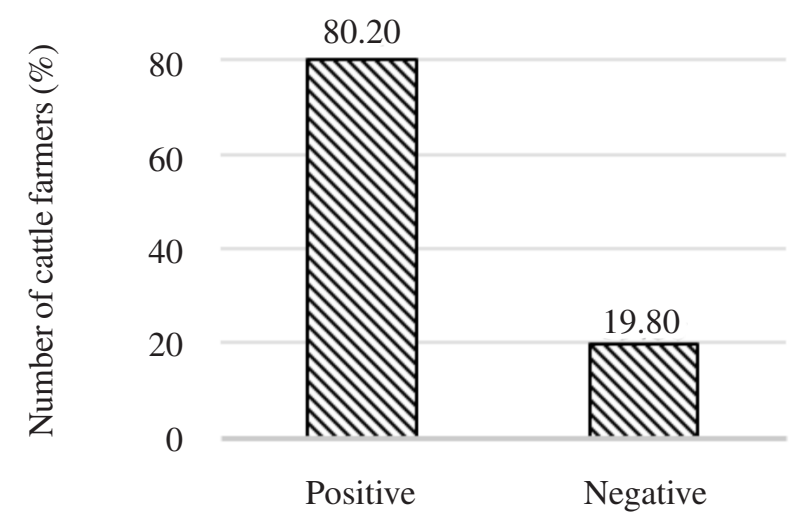

Knowledge of zoonotic diseases

Figure 2. Knowledge level of cattle farmers related to zoonotic diseases.

brucellosis, tuberculosis, rabies, CCHF, toxoplasmosis, hydatid cyst, or giardiasis?".

Regarding the infectious diseases transmitted from animals to humans, $69.6 \%$ (583) of the participants mentioned anthrax, 62.8\% (526) brucellosis, 18.4\% (154) tuberculosis, $44.9 \%$ (376) rabies, $32.5 \%$ (272) CCHF, $8.9 \%$ (75) hydatid cyst, $8.0 \%$ (67) toxoplasmosis and $7.9 \%$ (66) giardiasis (figure 3 ).

Table 1 shows the attitude and practices of cattle farmers toward zoonotic diseases. The question "Do animals need to be controlled regularly by a veterinarian?" was posed and 93.7\% (979) of them responded positively. In the case of the question "Do you arrange regular veterinarian controls for your animals?" 90.3\% (944) gave positive answers. However, when the frequency of this practice was asked, $33.8 \%$ (353) of them stated that they had their veterinarian control in two years period or more. Therefore, the answers

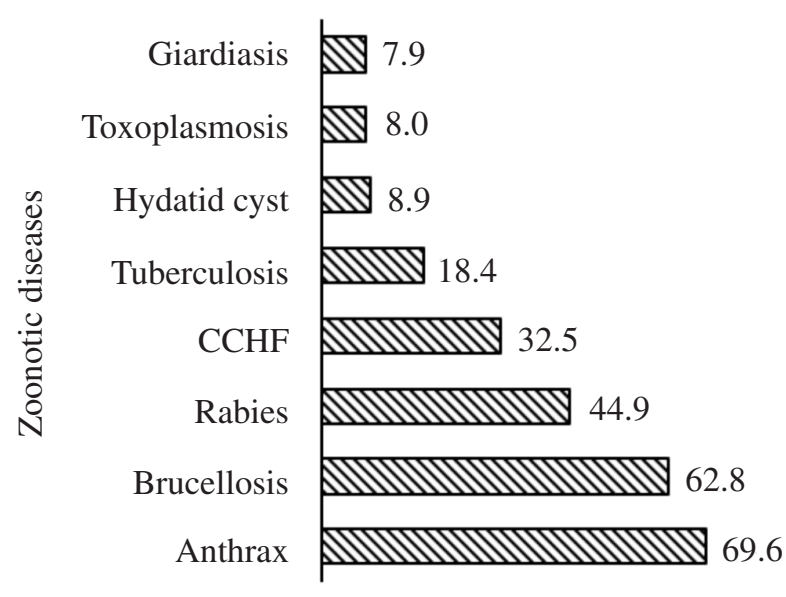

Number of cattle farmers (\%)

Figure 3. Knowledge level of cattle farmers related to the question "Which of these diseases infect humans?".

of cattle farmers who scheduled their control one year or less were accepted as positive while the data was being evaluated. The farmers requesting regular veterinarian controls were $57.1 \%$ (597) (table 2).

Along with $73.2 \%$ (765) cattle farmers thinking that gloves should be used in animal contact, there were $56.1 \%$ (586) cattle farmers mentioning the necessity of using masks. Those who use gloves and masks while in contact with animals had a ratio of $65.8 \%$ (688) and 23.9\% (250), respectively. Only $89.7 \%$ (937) of cattle farmers knew that they might be infected through a scar on the hand while contacting animals. It was detected that $19.8 \%$ (207) of cattle farmers continued to contact the animal with a scar on their hand. Regarding infected animals, 92.4\% (966) of cattle farmers stated that the dead body of an infected animal should be buried under the soil deeply. The percentage of those who exterminate the dead body in this way was $90.7 \%$ (948). While $80.0 \%$ (836) of cattle farmers said that milk needed to be boiled at least 5 minutes, the ones who actually boiled the milk at least five minutes were $76.7 \%$ (802) (table 2).

There were differences between the positive knowledge level, attitude and practices of cattle farmers regarding zoonotic diseases and their educational level, enterprises size, and monthly income. The positive knowledge level of illiterate farmers about zoonotic diseases was determined as $65.7 \%$ whereas those who graduated from university had a positive knowledge level of $94.8 \%$. On the other hand, despite the high knowledge level of university graduates, there was a decrease in the transformation of knowledge into positive practices as high as approximately $10 \%$. Regardless of the size of enterprises, all cattle farmers had a high level of positive knowledge about zoonotic diseases. However, their positive attitude and practice ratios were 
low. In enterprises having more than 100 cattle, $96.7 \%$ of cattle farmers had positive knowledge level, $95.1 \%$ had a positive attitude and $91.8 \%$ had positive practice. It was detected that there were differences in the positive knowledge, attitude, and practices of cattle farmers depending on their monthly income. The increase in monthly income was associated with an increase in the level of positive knowledge, attitude, and practices (table 3).

Table 2. The rates of positive attitude and practices of cattle farmers related to zoonotic diseases.

\begin{tabular}{lcccc}
\hline & \multicolumn{2}{c}{ Positive Attitude } & \multicolumn{2}{c}{ Positive Practice } \\
\cline { 2 - 4 } & $\mathrm{n}$ & $\%$ & $\mathrm{n}$ & \\
\hline Getting veterinary support for treatment & 982 & 94.0 & 947 & 90.6 \\
Making regular veterinarian control & 979 & 93.7 & 597 & 57.1 \\
Washing hand & 997 & 95.4 & 957 & 61.6 \\
Using glove & 765 & 73.2 & 688 & 65.8 \\
Using mask & 586 & 56.1 & 250 & 23.9 \\
Wearing boot & 903 & 86.4 & 903 & 78.3 \\
Avoid contact with scary hands & 937 & 89.7 & 838 & 80.2 \\
Disposal of animal carcass & 966 & 92.4 & 948 & 90.7 \\
Boiling milk & 836 & 80.0 & 802 & 76.7 \\
Make cheese with boiled milk & 908 & 86.9 & 813 & 77.8 \\
Avoid raw meat eating & 941 & 90.0 & 926 \\
\hline
\end{tabular}

$\mathrm{n}$ : Number of cattle farmers.

Table 3. Distribution of factors affecting positive knowledge, attitude and practices of cattle farmers related to zoonotic diseases.

\begin{tabular}{|c|c|c|c|c|c|c|c|c|c|c|}
\hline & \multirow{2}{*}{ Factors } & \multicolumn{3}{|c|}{ Knowledge } & \multicolumn{3}{|c|}{ Attitude } & \multicolumn{3}{|c|}{ Practice } \\
\hline & & $\begin{array}{c}\mathrm{n} \\
(\%)\end{array}$ & $\chi^{2}$ & $\mathrm{P}$ & $\begin{array}{c}\mathrm{n} \\
(\%)\end{array}$ & $\chi^{2}$ & $\mathrm{P}$ & $\begin{array}{c}\mathrm{n} \\
(\%)\end{array}$ & $\chi^{2}$ & $\mathrm{P}$ \\
\hline \multirow{5}{*}{ 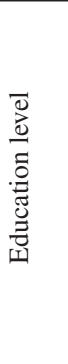 } & Illiterate & $\begin{array}{c}9 \\
(64.3)\end{array}$ & 31.934 & 0.0001 & $\begin{array}{c}9 \\
(64.3)\end{array}$ & 7.953 & 0.093 & $\begin{array}{c}8 \\
(61.1)\end{array}$ & 15.354 & 0.004 \\
\hline & Primary School & $\begin{array}{c}347 \\
(75.1)\end{array}$ & & & $\begin{array}{c}390 \\
(84.4)\end{array}$ & & & $\begin{array}{c}338 \\
(73.2)\end{array}$ & & \\
\hline & Secondary School & $\begin{array}{c}162 \\
(81.4)\end{array}$ & & & $\begin{array}{c}170 \\
(85.2)\end{array}$ & & & $\begin{array}{c}154 \\
(77.4)\end{array}$ & & \\
\hline & High School & $\begin{array}{c}203 \\
(86.0)\end{array}$ & & & $\begin{array}{c}206 \\
(87.4)\end{array}$ & & & $\begin{array}{c}195 \\
(82.6)\end{array}$ & & \\
\hline & University & $\begin{array}{c}127 \\
(94.8)\end{array}$ & & & $\begin{array}{c}120 \\
(89.6)\end{array}$ & & & $\begin{array}{c}113 \\
(84.3)\end{array}$ & & \\
\hline \multirow{5}{*}{ 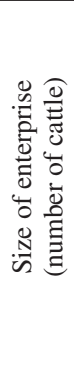 } & $<10$ & $\begin{array}{c}173 \\
(77.6)\end{array}$ & 15.164 & 0.004 & $\begin{array}{c}138 \\
(69.5)\end{array}$ & 63.985 & 0.0001 & $\begin{array}{c}110 \\
(61.9)\end{array}$ & 125.110 & 0.0001 \\
\hline & $10-30$ & $\begin{array}{c}318 \\
(80.4)\end{array}$ & & & $\begin{array}{c}352 \\
(89.1)\end{array}$ & & & $\begin{array}{c}322 \\
(81.5)\end{array}$ & & \\
\hline & $31-50$ & $\begin{array}{c}168 \\
(83.2)\end{array}$ & & & $\begin{array}{c}182 \\
(90.1)\end{array}$ & & & $\begin{array}{c}172 \\
(85.1)\end{array}$ & & \\
\hline & $51-100$ & $\begin{array}{c}142 \\
(86.8)\end{array}$ & & & $\begin{array}{c}150 \\
(91.5)\end{array}$ & & & $\begin{array}{c}143 \\
(87.2)\end{array}$ & & \\
\hline & $100<$ & $\begin{array}{c}59 \\
(96.7)\end{array}$ & & & $\begin{array}{c}58 \\
(95.1)\end{array}$ & & & $\begin{array}{c}56 \\
(91.8)\end{array}$ & & \\
\hline \multirow{3}{*}{ 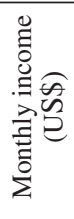 } & $<850$ & $\begin{array}{c}427 \\
(80.3)\end{array}$ & 21.860 & 0.0001 & $\begin{array}{c}466 \\
(87.6)\end{array}$ & 6.543 & $\underset{*}{0.034}$ & $\begin{array}{c}411 \\
(77.3)\end{array}$ & 16.154 & 0.0001 \\
\hline & $850-1700$ & $\begin{array}{c}394 \\
(89.5)\end{array}$ & & & $\begin{array}{c}401 \\
(91.1)\end{array}$ & & & $\begin{array}{c}376 \\
(85.4)\end{array}$ & & \\
\hline & $1700<$ & $\begin{array}{c}69 \\
(94.5)\end{array}$ & & & $\begin{array}{c}70 \\
(95.9)\end{array}$ & & & $\begin{array}{c}67 \\
(91.8)\end{array}$ & & \\
\hline
\end{tabular}

$* P<0.05, * * P<0.01, * * * P<0.0001$.

$\mathrm{n}$ : Number of cattle farmers. 


\section{DISCUSSION}

This study applied a broad concept in terms of the knowledge, attitude, and practices level of cattle farmers in Erzurum related to zoonotic diseases. Despite the knowledge level of cattle farmers about the diseases transmitted from animals to humans being high $(80.2 \%)$, their knowledge level to identify which diseases are zoonoses was low. Three out of 8 zoonotic diseases included in the questionnaire were identified as zoonoses by the cattle farmers (anthrax, brucellosis, and rabies). As for hydatid cyst, toxoplasmosis, and giardiasis diseases, their knowledge level was low (figure 3). Cattle farmers had a high level of knowledge about some of the zoonotic diseases probably because of the impact of mandatory vaccination campaigns targeting those diseases, applied to all bovines by the authorities in Turkey.

In our study, $69.6 \%$ of the cattle farmers knew that anthrax was a zoonotic disease and $62.8 \%$ of them also knew brucellosis. However, these ratios were much higher in a study conducted in Kars (Çakmur et al 2015). These differences between cities can be explained by the prevalence rate. In Turkey, between 1995 and 2010, the prevalence rate of anthrax cases was much higher in Kars when compared to Erzurum (Ertek 2011).

Turkey is still an endemic region in terms of rabies, with approximately 250,000 rabies-risk contact reports being made annually, averaging one to two rabies cases per year (Anonymous 2019). In our study, $44.9 \%$ of the cattle farmers knew that rabies was a zoonotic disease. However, the level of knowledge was not as high as in those who knew that anthrax and brucellosis were zoonoses. In a study conducted in Erzurum, $73 \%$ of the cases in emergency services due to the risk of rabies contact came from urban areas (Can et al 2020).

It was reported that the first human case of CCHF in 2002 was in Central Anatolia, Turkey. A total of 11,040 cases were reported in Turkey between 2002 and 2018, and 528 of them died (Anonymous 2019). In our study, $32.5 \%$ of the cattle farmers knew that CCHF was a zoonotic disease. Studies conducted in different provinces of Turkey have reported that knowledge about CCHF was insufficient (Ozer et al 2008, Yılmaz et al 2009, Çilingiroğlu et al 2010).

Inadequate personal hygiene and farming sanitation during close contact with animals, infected animal slaughtering and skin striping, wrong extermination of sick animal waste, and infected material can cause zoonotic diseases (Tebug et al 2015, Rajkumar et al 2016). Therefore, the people involved in such activities with livestock are always under a high risk in terms of zoonotic diseases (Martin et al 2011, Musallam et al 2015). In the study, among the preventive methods from zoonotic diseases, over $90 \%$ of cattle farmers had both positive attitudes and positive practices regarding handwashing after the contact with an animal, the burial of dead animal bodies, and separation of sick animals from the herd (table 2).

Only for treatment of their animals, $90.6 \%$ of cattle farmers had veterinary services whereas $57.1 \%$ had regular veterinary controls for their cattle. In a study conducted in the Çayırlı district of Erzincan, east of Erzurum, it was reported that $73.3 \%$ of dairy farmers benefitted from veterinary services when their animals were sick, $6.6 \%$ of them had regularly veterinary controls (Özyürek et al 2014). In our research, the frequency of practices such as wearing boots inside the enterprise (78.3\%) and using gloves while in contact with animals $(65.8 \%)$ was higher than the practice of using a mask (23.9\%) (table 2). Odo et al (2015) and Munisamy et al (2017) reported percentages related to the use of gloves (51\% and $36.8 \%$ respectively) and masks (26.0\% and $18.4 \%$ respectively) among livestock farmers that were lower than those in our research.

Production of animal products, contaminations during this production, wrong feeding habits and lack of knowledge can be effective in the transmission of zoonotic diseases (Tebug et al 2015, Rajkumar et al 2016). It must be highlighted that through the consumption of raw milk and milk products, several bacterial zoonotic diseases can infect people except for brucellosis and tuberculosis (Özlü and Atasever 2018). In this study, nearly $3 / 4$ of cattle farmers mentioned that they consumed milk after a minimum of five minutes of boiling and did not make cheese from raw milk. A research conducted on sheep and goat farmers in the Van province, located in Southeast Erzurum, and in the same geographical region (Eastern Anatolia Region), showed that most of the participants made cheese from raw milk and some consumed the cheese they made freshly. (Kuşaslan Avcı et al 2017). In a meta-analysis study done on the awareness level of brucellosis disease globally (21 studies), it was found that ratio of awareness was $44.5 \%$ that raw milk consumption for being a risk factor for brucellosis. (Zhang et al 2019). In our study, attitude and practice levels of cattle farmers regarding the topic of non-consumption of raw milk and cheese made from raw milk were high.

Although raw meat consumption has been applied for generations in many social groups located in Russia, Cuba and Africa (Abera et al 2016), there is no habit of raw meat consumption in our country. Raw meat consumption creates dangerous situations in terms of public health due to parasite diseases originated from food as well as bacterial diseases (Murrell 2013, Bintsis 2017). Although Erzurum is a city with high red meat consumption, $88 \%$ of cattle farmers included in the questionnaire answered that they did not consume raw meat. This situation showed similarity with the work of Çakmur et al (2015). Zoonotic diseases constitute $70 \%$ of community-acquired diseases.

In relation to the occurrence of these diseases, it is known that sociocultural habits and socioeconomic conditions have a strong influence (Dinçer et al 2003). If factors such as socioeconomic status of cattle farmers, their 
education levels, and the enterprise sizes are considered, it is important to put forward the risks of enterprises related to zoonotic diseases, prevent these diseases and develop control strategies. In this research, no significant differences were found between "ages of the cattle farmers" and "their knowledge, attitude, and practices about zoonotic diseases" $(P>0.05)$. However, there was a significant difference between "education levels, enterprise sizes, income levels" and "knowledge, attitude, and practices toward zoonotic diseases" $(P<0.05)$.

When the knowledge and practice of cattle farmers related to zoonotic diseases were compared with their education status, there was a significant difference between groups $(P<0.01)$, but if only their attitudes were compared, it was observed that there was no significant difference. It was confirmed that especially the ones who had high school and university education had a knowledge level distinctly higher and their attitude and practices, except for those who were not illiterate, were closely related to each other. In the same manner, studies conducted in Tajikistan, Senegal, Nepal, and India reported that livestock farmers with low education level had a low level of knowledge, attitude, and practices toward protection from zoonotic diseases (Lindahl et al 2015, Tebug et al 2015, Kelly et al 2018, Prasad et al 2019).

It was confirmed that especially the ones who had high school and university education had knowledge level distinctly higher and their attitude and practices, except for those who were not illiterate, were closely related to each other. In the same manner, studies conducted in Tajikistan, Senegal, Nepal, and India reported that livestock farmers with low education level had low level of knowledge, attitude, and practices toward protection from zoonotic diseases (Lindahl et al 2015, Tebug et al 2015, Kelly et al 2018, Prasad et al 2019).

Small scale livestock enterprises play a significant role as a source of income and feeding for low and middle-income countries (Herrero et al 2013). Small scale and poor livestock farmers are more often affected by animal diseases, which reduce their income and kill or weaken their animals, destroying much of their food resources and assets (Pradere 2014). In this study, as the number of animals increased in cattle enterprises, knowledge, attitude, and practice levels of cattle farmers also increased. It was also observed that there was a significant difference between groups $(P<0.01)$. It was found that most of the cattle farmers included in the questionnaire had a high level of knowledge related to zoonotic diseases and also a high level of knowledge regarding the attitude causing the infection of these diseases but they did not transform that knowledge into practice evenly. Cattle farmers who had more than 100 cattle had knowledge, attitude, and practices toward zoonotic diseases at a level of over $90 \%$ and it was higher than other groups (table 3 ). At the same time, most of the enterprises with more than 100 cattle were having regular veterinary surgeon services. This situation decreases the cost of veterinarian service per unit as the number of animal increases. In any case, cost increase causes small and middle scale enterprises to benefit less from veterinarian service depending on the decrease in the animal count (Haan and Umali 1992).

Livestock farming composes at least $70 \%$ of poor people's mainstay who live in rural areas in the world (Schelling et al 2007). Animal production accounts for $64 \%$ of the agricultural economy of Erzurum and it is one of the primary sources of income for the community (Çoban et al 2013). In this study, when the monthly income of cattle farmers was compared with their knowledge, attitude, and practices toward zoonotic diseases, the difference was significant $(P<0.05)$. It was observed that as the monthly income increased, cattle farmers' knowledge, attitude, and practice levels also increased. Nearly all of the enterprises having more than 100 cattle had a monthly income of over US\$1,700 (table 3). In major scale enterprises, regardless of the count, one or more animals being sick can affect the health of all animals negatively. For this reason, cattle farmers are well aware of keeping a budget for taking veterinarian service in protection of animal health and treatment.

In Erzurum province, where cattle farming is performed intensely, the knowledge, attitude, and practice levels of cattle farmers increased depending on the increase in their education level, their enterprise size and their monthly income. However, regardless of education level, enterprise size and monthly income, it was determined that the positive application levels of all cattle farmers were always lower than the positive attitude levels. Further studies are needed to identify the reasons for the low level of positive practices among cattle farmers. Besides, to prevent and decrease the risks of zoonotic diseases throughout the city, cattle farmers should be given training on topics such as public health, animal health, food security, environment protection, personal cleaning and hygiene. By conducting such studies and providing training to livestock farmers, the opportunity to intervene in a number of zoonotic disease transmission cycles can be improved. It could also be applied to the One Health approach, i.e. public veterinary, environmental and human health function as part of an integrative system.

\section{ACKNOWLEDGEMENTS}

This work was supported by Atatürk University Scientific Research Project Unit (BAP ID:2765-PRJ2015/59).

\section{REFERENCES}

Abera G, Kumar N, Gebrewahd T, Yizengaw H. 2016. Study on assessment of community awareness towards common zoonotic diseases in and around Asella, Eastern Arsi Zone, Ethiopia. J Livest Prod 6, 1. Anonymous. 2019. Türkiye Zoonotik Hastalıklar Eylem Planı (20192023). Sağlık Bakanlığı Yayını, Ankara, Türkiye, Pp 101. 
Ateş HÇ, Terin M. 2008. Hayvancılığa yönelik yapılan kalkınma ve yayım çalışmalarının genel bir değerlendirmesi: Van ili örneği. Uludag Üniv Ziraat Fak Derg 22, 7-16.

Bintsis T. 2017. Foodborne pathogens. AIMS Microbiol 3, 529-563.

Can FK, Tekin E, Sezen S, Clutter P. 2020. Assessment of rabies prophylaxis cases in an emergency service. J Emerg Nurs In Press, Corrected Proof, Available online 14 May 2020.

Cediel N, Conte V, Tomassone L, Tiberti D, Guiso P, et al. 2012. Risk perception about zoonoses in immigrants and Italian workers in Northwestern Italy. Rev Saude Publica 46, 850-857.

Çakmur H, Akoğlu L, Kahraman E, Atasever M. 2015. Evaluation of farmers' knowledge-attitude-practice about zoonotic diseases in Kars, Turkey. Kafkas J Med Sci 5, 87-93.

Çilingiroğlu N, Temel F, Altintaş H. 2010. Public's knowledge, opinions and behaviors about Crimean-Congo hemorrhagic fever: An example from Turkey. Kafkas Univ Vet Fak Derg 16 (Suppl-A), S17-S22.

Çoban O, Lacin E, Sabuncuoglu N, Genc M. 2013. Production and health parameters in cattle herds: A survey from eastern Turkey. J Anim Plant Sci 23, 1572-1577.

Dinçer B, Özaslan M, Kavasoğlu T. 2003. İllerin sosyo-ekonomik gelişmişlik sıralamasının araştırması. DPT 2671, Ankara, Turkey, Pp 6-18.

Ertek M. 2011. Şarbonun ülkemizdeki durumu. Ankem Derg 25, 88-91.

Fèvre EM, Bronsvoort BM, Hamilton KA, Cleaveland S. 2016. Animal movements and the spread of infectious diseases. Trends Microbiol 14, 125-131.

Haan CD, Umali DL. 1992. Public and private sector roles in the supply of veterinary services. Proceedings of the Twelfth Agricultural Sector Symposium, Washington DC:The World Bank.

Hardstaff JL, Hasler B, Rushton JR. 2015. Livestock trade networks for guiding animal health surveillance. BMC Vet Res 11, 82 .

Herrero M, Grace D, Njuki J, Johnson N, Enahoro D, et al. 2013. The roles of livestock in developing countries. Animal 7, 3-18.

İnci A, Doğanay M, Özdarendeli A, Düzlü Ö, Yıldırım A. 2018. Overview of zoonotic diseases in Turkey: The one health concept and future threats. Turkiye Parazitol Derg 42, 39-80.

Kelly TR, Bunn DA, Joshi NP, Grooms D, Devkota D, et al. 2018. Awareness and practices relating to zoonotic diseases among smallholder farmers in Nepal. EcoHealth 15, 656-669.

Kuşaslan Avcı D, Sahin HA, Güvendi G, Çakmak Z. 2017. Determination of information, behavior and attitudes on brucellosis of dairy farmers in a village in Van. Van Med J 24, 78-84.

Lindahl E, Sattorov N, Boqvist S, Magnusson U. 2015. A study of knowledge, attitudes and practices relating to brucellosis among small-scale dairy farmers in an urban and peri-urban area of Tajikistan. PloS One 10, e0117318.

Magwedere K, Hemberger MY, Hoffman LC, Dziva F. 2012. Zoonoses: A potential obstacle to the growing wildlife industry of Namibia. Infect Ecol Epidemiol 2, 10.3402/iee.v3402i3400.18365.

Martin C, Pastoret PP, Brochier B, Humblet MF, Saegerman C. 2011. A survey of the transmission of infectious diseases/infections between wild and domestic ungulates in Europe. Vet Res 42, 70.

Ministry of Health. 2011. Zoonotik hastalıklar hizmet içi eğitim modülü. Temel Sağlık Hizmetleri Genel Müdürlüğü, Zoonotik Hastalıklar Daire Başkanlığı, TC Sağlık Bakanlığı, Ankara, Turkey, Pp 1-85.

Munisamy B, Sivanathan PP, Kannan P. 2017. Knowledge assessment through surveying on cattle zoonotic diseases in dairy farmers. Int J Curr Microbiol Appl Sci 6, 783-794.

Murrell KD. 2013. Zoonotic foodborne parasites and their surveillance. Rev Sci Tech 32, 559-569.
Musallam II, Abo-Shehada MN, Guitian J. 2015. Knowledge, attitudes, and practices associated with brucellosis in livestock owners in Jordan. Am J Trop Med Hyg 93, 1148-1155.

Odo NU, Raynor PC, Beaudoin A, Somrongthong R, Scheftel JM, et al. 2015. Personal protective equipment use and handwashing among animal farmers: a multi-site assessment. J Occup Environ Hyg 12, 363-368.

Ozer A, Miraloglu M, Ekerbicer HC, Cevik F, Aloglu N. 2008. Knowledge levels about Crimean-Congo hemorrhagic fever among midwifery and nursing students in Kahramanmaras, Turkey. Southeast Asian J Trop Med Public Health 41,77-84.

Özlü H, Atasever M. 2018. Gıda kaynaklı bakteriyel zoonozlar. In: Duran N (ed). Current Academic Studies in Health Sciences. Ivpe, Cetinje, Montenegro, Pp 262-269.

Özyürek S, Koçyiğit R, Tüzemen N. 2014. Erzincan ilinde süt sığırcılığı yapan işletmelerin yapısal özellikleri: Çayırlı ilçesi örneği. Structural features of dairy farmers in the Erzincan: the example of Çayırlı district. J. Tekirdag Agric. Fac. 11, 19-26.

Pradere JP. 2014. Improving animal health and livestock productivity to reduce poverty. Rev Off Int Epizoot 33, 735-744.

Prasad MCB, Vineesha L, Raj A, Bhattacharyya S, Banik A. 2019. A socio-demographic study on extent of knowledge, attitude and risk of zoonotic diseases among livestock owners in Singur, West Bengal. East African Scholars J Med Sci 2, 154-158.

Rajkumar K, Bhattacharya A, David S, Balaji SH, Hariharan R, et al. 2016. Socio-demographic study on extent of knowledge, awareness, attitude, and risks of zoonotic diseases among livestock owners in Puducherry region. Vet World 9, 1018-1024.

Salyer SJ, Silver R, Simone K, Barton Behravesh C. 2017. Prioritizing zoonoses for gglobal health capacity building-Themes from one health zoonotic disease workshops in 7 countries, 2014-2016. Emerg Infect Dis 23, S55-S64.

Schelling E, Grace D, Willingham A, Randolph T. 2007. Research approaches for improved pro-poor control of zoonoses. Food Nutr Bull 28, S345-356.

Shanko K, Kemal J, Kenea D. 2015. A review on confronting zoonoses: The role of veterinarian and physician. J Vet Sci Technol 6, 221.

Tebug S, Kamga-Waladjo AR, Ema P, Munyaneza C, Kane O, et al. 2015. Cattle farmer awareness and behavior regarding prevention of zoonotic disease transmission in Senegal. J Agromedicine 20, 217-224.

Tomassone L, Berriatua E, De Sousa R, Duscher GG, Mihalca AD, et al. 2018. Neglected vector-borne zoonoses in Europe: Into the wild. Vet Parasitol 251, 17-26.

TUIK, Turkish Statistical Institute. 2018. Livestock Statistics. Prime Ministry, Republic of Turkey.

Ünal Ç. 2011. Erzurum'un tarım potansiyeli/The agricultural potential of Erzurum. Doğu Coğrafya Dergisi 8, 10.

Weese JS, Peregrine AS, Armstrong J. 2002. Occupational health and safety in small animal veterinary practice: Part I-Nonparasitic zoonotic diseases. Can Vet J 43, 631-636.

Yilmaz R, Ozcetin M, Erkorkmaz U, Ozer S, Ekici F. 2009. Public knowledge and attitude toward Crimean Congo hemorrhagic fever in Tokat Turkey. Iran J Arthropod Borne Dis 3, 12-17.

Zhang N, Zhou H, Huang DS, Guan P. 2019. Brucellosis awareness and knowledge in communities worldwide: A systematic review and meta-analysis of 79 observational studies. PLoS Negl Trop Dis 13, e0007366. 
